\section{Aktuelt og velskrevet om studenters psykiske helse}

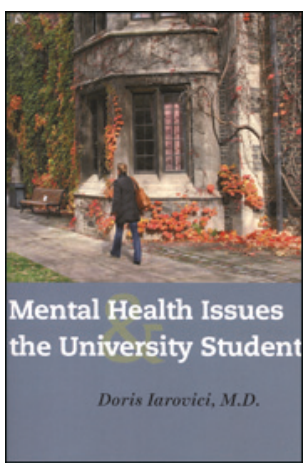

\author{
Doris larovici \\ Mental health issues and the university \\ student
}

248 s, tab, ill. Baltimore, MD: The Johns

Hopkins University Press, 2014. Pris USD 35

ISBN 987-1-4214-1238-2
Iarovici har lang erfaring som psykiater i amerikansk studenthelsetjeneste, og hun henvender seg her til annet helsepersonell, fortrinnsvis psykiatere, som også jobber med studenter som trenger hjelp. I første del av boken argumenterer hun for at studentenes psykiske helse i løpet av de siste 20 årene har blitt markant dårligere. Hun beskriver endringer i studentmassen og studentenes levesett og understreker viktigheten av at helsepersonell er klar over disse forholdene. I bokens hoveddel tar forfatteren for seg, kapittel for kapittel, psykiske helseutfordringer som er vanlige blant studenter. Boken er rik på vignetter, som hun tar utgangspunkt i når hun utforsker mulige intervensjoner. Hun refererer dessuten til forskningsfunn og statistikk, samt i noe grad til psykologisk teori for å belyse alternative tilnærmingsmåter. Blant temaene hun dekker, er depresjon og angst, spiseforstyrrelser og rusproblemer, men også andre ikke så ofte berørte emner som perfeksjonisme og søvnproblemer, ensomhet og relasjonelle vansker.

Boken er oversiktlig og meget velskrevet. Den prisbelønte forfatteren skriver klinikknært og engasjerende og integrerer egen erfaring med oppdatert kunnskap fra behandlingsforskning og siste revisjon av diagnosemanualen (DSM-V). Hun hevder at det vanskeligste, men også det mest spennende, i arbeidet med studenter er hvordan man kan skille psykopatologi fra forbigående besvær som i noen grad preger de aller fleste i denne livsfasen. Iarovici presenterer grundige redegjørelser for denne krevende øvelsen for hvert enkelt tema. Til tross for at hun setter rammene for utgivelsen med kapitlet «Crisis on the college campus?», påpeker hun at studenter er kvikke, motiverte og en spennende pasientgruppe å jobbe med. De er unge og fortsatt i støpeskjeen, noe som gir en gyllen anledning til å intervenere tidlig og bidra til å endre deres liv.

Noe påfallende er det at forfatteren gjennom teksten i all hovedsak henvender seg til psykiateren, mens hun i etterordet vektlegger viktigheten av å samarbeide på tvers av profesjoner. Selv om en del av materien hun berører handler om medisinering, vil jeg påstå at størsteparten av innholdet ikke er psykiaterspesifikt og med fordel kan leses av psykologer, psykiatriske sykepleiere og andre som driver samtaleterapi med studenter.

Nylig viste en rapport at forekomsten av alvorlige psykiske symptomer blant norske studenter er dobbelt så høy som i normalbefolkningen i samme aldersgruppe. Dette trekker i samme retning som Iarovicis retoriske spørsmål «Crisis on the college campus?» og bør bidra til en økt interesse for studenters psykiske helsebehov. Boken anbefales ikke bare til helsepersonell som jobber med studenters psykiske helse, men også til de med ansvar for organisering av studenthelsetjenesten.

Kjersti Støen Grotmol

Postdoktor, Avdeling for medisinske atferdsfag

Universitetet i Oslo

\section{En lærebok om pasientsikkerhet og kvalitetsforbedring i helsetjenesten}

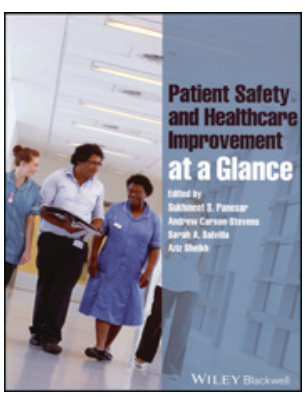

Sukhmeet S. Panesar, Andrew Carson-

Stevens, Sarah A. Salvilla et al, red.

Patient safety and healthcare improvement at a glance

124 s, tab, ill. Chichester: Wiley-Blackwell, 2014. Pris GBP 27

ISBN 978-1-118-36136-8

Fokuset på pasientsikkerhet og kvalitetsforbedring $\mathrm{i}$ helsetjenesten har økt i betydning og omfang de seneste årene. Denne læreboken gir en bred presentasjon fra teori til spesifikke metoder for bruk på forskjellige faglige områder. Språket er engelsk, og for å fremme et klart og direkte språk har studenter lest gjennom manuset.

124 sider høres ikke mye ut, men forfatterne har klart å presentere mye stoff på en kortfattet og tydelig måte, med utstrakt bruk av illustrasjoner, faktabokser og tabeller. Boken er delt inn i fire deler. Del 1 er en innføring i betydning og teori om pasientsikkerhet og utviklingen innenfor kvalitetsarbeid. Det fokuseres både på verdier, systemfaktorer og relasjoner mellom menneskelige faktorer og systembetingede faktorer. Del 2 omhandler forståelse og tolkning av risiko. Det beskrives etablerte metoder for å kartlegge viktige faktorer til bruk ved evalueringer og kvalitetsindikatorer i forbedringsarbeidet. Del 3 omhandler risiko ved pasientbehandling som medikamentfeil, diagnosefeil m.m. Det beskrives flere typer tiltak for å analysere årsaker og for å redusere risiko. Del 4 dekker arbeid med kvalitetsforbedring innenfor 17 ulike områder og ved hjelp av ulike metoder.

Illustrasjonene er klare og tydelige, og de er like viktige som teksten for å sette leseren fort inn i de beskrevne metoder og analyseverktøy. Det understrekes at god forståelse av problemstillingen, systematisk analyse og måling av effekt av nye tiltak er viktig.

Boken er til nytte for studenter, leger og ledere som er interessert i hvordan man kan analysere situasjoner og arbeide med pasientsikkerhet og kvalitetsforbedring. Utgivelsens styrke er den bredden i metodiske tilnærminger som beskrives, og at disse er knyttet opp mot mange fagfelt. Etter å ha gjennomgått teksten får man en meget nyttig oversikt over hvilke metoder man kan anvende for å drive med begrunnet og fokusert kvalitetsforbedring for å fremme pasientsikkerhet i de forskjellige delene av helsetjenesten. Boken anbefales!

Lise Lund Håheim

Seniorforsker, Nasjonalt kunnskapssenter for helsetjenesten 